\title{
Detection of Monosomy 7 in Interphase Cells of Patients With Myeloid Disorders
}

\author{
Rukmini V. Kolluri, Laura Manuelidis, Thomas Cremer, Sheila Sait, Sefer Gezer, \\ and Azra Raza \\ Departments of Human Genetics (R.V.K.), Genetics and Endocrinology (S.S.), and Hematologic Oncology (S.G., A.R.), \\ Roswell Park Memorial Institute, Buffalo, New York; Section of Neuropathology, Yale University School of Medicine, New Haven, \\ Connecticut (L.M., T.C.)
}

\begin{abstract}
Six patients, five with acute myeloid leukemia (AML) and one with a myelodysplastic syndrome (MDS), were found to have monosomy 7 by conventional cytogenetics at diagnosis. Repetitive DNA sequences from the heterochromatic region of human chromosomes 1 and 7 were used as probes for in situ hybridization experiments on interphase cells of these patients. A double hybridization protocol was used to reveal the particular chromosomes as distinct spots or clusters of signals within interphase nuclei. The chromosome 1 sequence served as an internal control. Simultaneous detection of the sequences showed the presence of two normal number 1 chromosomes and a missing 7 chromosome from individual cells. While cytogenetic preparations showed only -7 metaphases in 3 AML and 1 MDS patients, in situ hybridization of interphase cells showed many normal cells as well as the presence of -7 in fully mature granulocytes. One AML patient studied in remission showed only normal metaphases yet had $9 \%$ interphase cells with a missing 7 and relapsed within 3 months. We conclude that examination of interphase cells by in situ hybridization provides clinically useful data since every cell including mature granulocytes can be examined, the lineage of a cell can be determined, and efficacy of differentiation therapy can be evaluated.
\end{abstract}

Key words: maturation in cancer cells, AML, interphase cytogenetics

\section{INTRODUCTION}

The possibility that leukemic cells of patients with myeloid leukemias can be induced to differentiate has been an appealing alternative to aggressive remission induction chemotherapy $[1,2]$. Before the efficacy of a variety of inducing agents can be practically tested however, direct proof that a mature cell has actually been derived from the leukemic clone is required. Since mature cells do not enter mitosis, classical cytogenetic proof of such clonal origin cannot be obtained. Recently, it has become possible to identify individual chromosomes in interphase cells [3-6]. This is accomplished by using in situ hybridization with cloned DNA probes that detect specific repetitive target DNA sequences present in individual chromosomes. By using multicolor detection of multiple chromosome specific DNA probes, more than one chromosome can be identified in an individual interphase cell [7].

We identified five patients with acute myeloid leuke- mia (AML) and one with a myelodysplastic syndrome (MDS) who had monosomy 7 detected by conventional cytogenetic techniques. Using a probe $(\mathrm{p} \alpha 7 \mathrm{tl})$ specific for the pericentromeric region of chromosome 7 , we were able to demonstrate the presence of -7 abnormality in interphase cells of these individuals. Simultaneous detection of two different nucleic acid sequences demonstrated the presence of two normal number 1 chromosomes and a missing chromosome 7 in individual cells. This report describes the cytogenetic data and in situ hybridization findings in these six patients with AML and MDS.

Received for publication June 21, 1989; accepted September 26, 1989.

Address reprint requests to Azra Raza, M.D., Director, Hematologic Oncology Program, UC Medical Center (ML 508), 231 Bethesda Ave, Cincinnati, OH 45267. 


\section{MATERIALS AND METHODS}

Six patients with myeloid disorders were the subject of this study. Five individuals had a diagnosis of AML and one patient suffered from MDS. Bone marrow (BM) aspirates and/or peripheral blood (PB) samples were obtained from every patient into a plastic syringe containing $2 \mathrm{ml}$ of $6 \%$ sodium citrate. Informed consent was obtained from each patient. Cytogenetic studies were performed on short-term cultures of heparinized samples by using standard G-banding methods. For identification of specific chromosomes in interphase cells, the following methods were utilized:

\section{Sample Preparation}

Bone marrow aspirates or peripheral blood samples were layered on Ficoll Hypaque (specific gravity 1.077) and centrifuged at $1,200 \mathrm{~g}$ for $30 \mathrm{~min}$. The light density cells were recovered, washed in PBS, and treated with hypotonic $\mathrm{KCl}(0.075 \mathrm{M})$ for $30 \mathrm{~min}$ at $37^{\circ} \mathrm{C}$ or deposited onto precleaned glass microscope slides by cytocentrifugation. Subsequently the cells were fixed with several changes of methanol/acetic acid $(3: 1, \mathrm{v} / \mathrm{v})$. Cells fixed in suspension were dropped onto ethanol cleaned slides. The slides were dried overnight in a hot air oven at $65^{\circ} \mathrm{C}$ and stored in sealed boxes at $4^{\circ} \mathrm{C}$ until use.

\section{DNA Probes}

Probe puc 1.77 represents a $1.77 \mathrm{~KB}$ EcoRI fragment of human satellite III DNA family cloned in puc $9[8]$ and is located predominantly on chromosome 1 . The probe po7tl contains a $680 \mathrm{bp}$ EcoRI fragment of alphoid DNA cloned in puc9 and is specific for chromosome 7 using higher stringency conditions [9]. After in situ hybridization both sequences light up only the pericentromeric hetero-chromatic region of their corresponding chromosomes.

Probe $p \alpha 7 \mathrm{tl}$ was chemically modified by nick translation with biotin-labeled deoxyuridine triphosphate (bio11-dUTP) (BRL) to a mean size of 200-400 bp [10]; puc 1.77 was modified by treatment with 2-acetylaminofluorene (AAF) according to method of Landegent et al. [11] and sonicated in $10 \mathrm{mM}$ Tris/ImMEDTA buffer to yield $200-400$ bp fragments as analyzed by gel electrophoresis.

\section{In Situ Hybridization}

Hybridizations were performed as described [7] by using $60 \%$ Formamide $2 \times \mathrm{SSC}(1 \times \mathrm{SSC}$ is $0.15 \mathrm{M} \mathrm{NaCl}$, $0.015 \mathrm{M}$ sodium citrate) to suppress non-specific chromosome hybridization. The labeled probes puc 1.77 (AAF) and pa7tl (Biotin) were used in combination at a final concentration of $1-2 \mu \mathrm{g} / \mathrm{ml}$. The hybridization mixture was applied to the slides under a coverslip $\left(3 \mu \mathrm{l} / \mathrm{cm}^{2}\right)$ which was sealed with rubber cement. Denaturation of probe and cellular target DNA was carried out by heating the slides to $80^{\circ} \mathrm{C}$ for $10 \mathrm{~min}$ in a hot air oven. Hybridization was carried out for $16-18 \mathrm{hr}$ in a moist chamber at $37^{\circ} \mathrm{C}$. After hybridization the slides were washed at $45^{\circ} \mathrm{C}(50 \%$ Formamide $/ 2 \times \mathrm{SSC}, \mathrm{pH} 7.0$, three times for 10 min each followed by washes with $4 \times \mathrm{SSC}, \mathrm{pH} 7.0$, twice for $10 \mathrm{~min}$ each, and finally a wash with $0.1 \times \mathrm{SSC}$, $\mathrm{pH} 7.0$, at $65^{\circ} \mathrm{C}$, twice for $10 \mathrm{~min}$ each) and immersed in PN-buffer $(0.1 \mathrm{M}$ sodium phosphate, $0.05 \%$ Nonidet $\mathrm{P}$ $40, \mathrm{pH} 8.0$ ). The stringency of hybridization conditions is crucial in order to avoid cross hybridization with related sub-families present on other chromosomes. When the stringency is somewhat decreased, hybridization signals become apparent on other chromosomes [3].

\section{Cytochemical Detection}

Detection of target sites was carried out as described [7] by using streptavidin $(2 \mu \mathrm{g} / \mathrm{ml})$ combined with mouse monoclonal antibodies against $\mathrm{AAF}(1: 300$, gift of R.A. Baan, The Netherlands) in the primary reaction. The secondary reaction included biotinylated alkaline phosphatase combined with goat antimouse IgG conjugated with fluorescein isothiocyanate (FITC) (1:200, Sigma). Alkaline phosphatase was developed with nitro blue tetrazolium choride (NBT) and 5-bromo-4-chloro-3-indolyl phosphate (BCIP) for $1 \mathrm{hr}$ at $37^{\circ} \mathrm{C}$ [7], counterstained with DAPI $(200 \mathrm{mg} / \mathrm{ml})$ for total DNA, and mounted in an antifade solution. Microphotographs were taken on a Nikon microscope equipped for FITC and DAPI fluorescence. A small amount of transmitted light was used to improve the photographic signal of the alkaline phosphatase reaction in the DAPI stained nuclei.

\section{RESULTS}

Table I summarizes the clinical data on the six patients who are the subject of this report. Five had a diagnosis of AML. Three were studied at the time of relapse or refractory leukemia, one (JG) during complete remission (CR), and one (PS) after she received an allogeneic bone marrow transplant from her HLA-matched brother. The last patient in Table I (TA) has had a diagnosis of myelodysplasia for $5 \mathrm{yr}$ with an indolent, relatively benign course.

Cytogenetic examination with conventional G-banding revealed the presence of monosomy 7 in all of these patients prior to chemotherapy. The first three AML patients were studied for interphase cytogenetics when they had active leukemia. The -7 abnormality was noted in almost all metaphases $(100 \%, 100 \%$, and $95 \%$ respectively) (Table 1). JG and PS were studied during complete remission and post bone marrow transplantation respectively. They both demonstrated only normal metaphases even though each had monosomy 7 in $100 \%$ 


\begin{tabular}{|c|c|c|c|c|c|c|c|c|c|c|c|}
\hline \multirow[b]{3}{*}{ No. } & \multirow[b]{3}{*}{ Name } & \multirow{3}{*}{$\begin{array}{l}\text { Sample } \\
\mathrm{PB} / \mathrm{BM}\end{array}$} & \multirow{3}{*}{$\begin{array}{c}\text { Dx } \\
\text { FAB type }\end{array}$} & \multirow[b]{3}{*}{ Status } & \multirow[b]{3}{*}{$\%$ blast } & \multicolumn{4}{|c|}{$\begin{array}{c}\text { Differential in situ hybridization, } \\
\% \text { (No. interphase cells) }\end{array}$} & \multirow{2}{*}{\multicolumn{2}{|c|}{$\begin{array}{l}\text { Cytogenetics, \% } \\
\text { (No. metaphases) }\end{array}$}} \\
\hline & & & & & & & \% Lymphs & $\begin{array}{l}-7 \text { cells, } \\
2 \text { chromosome } 1\end{array}$ & $\begin{array}{l}N \text { cells, } \\
2 \text { chromosome } 1,\end{array}$ & & \\
\hline & & & & & & $\% \mathrm{PMN}$ & + Monos & 1 chromosome 7 & 2 chromosome 7 & 7 cells & $N$ cells \\
\hline \multirow[t]{2}{*}{1} & sw & PB & AML & Refr. Dis. & 86 & 0 & 14 & 82 & 8 & 100 & 0 \\
\hline & & & FAB M1 & & & & & $(172)$ & (16) & (20) & (0) \\
\hline \multirow[t]{2}{*}{2} & RS & PB & AML & Refr. Dis. & 73 & 17 & 5 & 75 & 15 & 100 & 0 \\
\hline & & & FAB M2 & & & & & (162) & (33) & $(27)$ & $(0)$ \\
\hline \multirow[t]{2}{*}{3} & $\mathrm{JC}$ & BM & AML & REL & 46 & 4 & 40 & 77 & 12 & 95 & 5 \\
\hline & & & FAB M1 & & & & & $(160)$ & (25) & (19) & (1) \\
\hline \multirow[t]{2}{*}{4} & JG & PB & AML & REM. & 0 & 59 & 37 & 9 & 74 & 0 & 100 \\
\hline & & & FAB M4 & & & & & (18) & $(153)$ & $(0)$ & $(20)$ \\
\hline \multirow[t]{2}{*}{5} & PS & BM & AML & S/P BM & 3 & 21 & 19 & 4 & 80 & 0 & 100 \\
\hline & & & FAB M7 & Transplt. & & & & (8) & $(167)$ & $(0)$ & $(30)$ \\
\hline \multirow[t]{4}{*}{6} & TA & PB & MDS & MDS & 0 & 9 & 87 & (117) & (158) & 100 & 0 \\
\hline & & & & & & & & 58 & 29 & $(20)$ & (0) \\
\hline & & PB & & & 2 & 12 & 86 & 63 & 25 & 100 & 0 \\
\hline & & & & & & & & (124) & (49) & & \\
\hline
\end{tabular}

$* \mathrm{~PB}=$ peripheral blood; $\mathrm{BM}=$ bone marrow; $\mathrm{Dx}=$ diagnosis; $\mathrm{AML}=$ acute myeloid leukemia; Refr. Dis. $=$ refractory disease; $\mathrm{REM}=$ remission; $\mathrm{N}$ cells = normal cells; S/P BM Transplt. = status post allogeneic bone marrow transplant; MDS = myelodysplastic syndrome; PMN = polymorphonuclear leukocytes; Lymphs = lymphocytes; Monos = monocytes.

metaphases of bone marrow specimens examined 3 months and 7 months prior to this study. Finally, TA has had several cytogenetic examinations in the last few years. He has consistently demonstrated the presence of monosomy 7 in all the metaphases examined during this time. Occasionally, TA has hypodiploid cells which demonstrate random chromosome loss in addition to the monosomy 7 . It is worthwhile to note that TA has not received any cytotoxic chemotherapy. Additional chromosomal abnormalities were only identified in patient JG who had inv(16) in addition to monosomy 7 in 7 of 11 metaphases at the time of diagnosis. Occasional random loss of chromosomes was observed in other patients, but no other definite clonal abnormalities were identified. Table II presents the numberical scoring of interphase cells obtained from either "normal" blood or bone marrow as well as the details of results obtained in all patients being reported in Table I. It can be seen that even in normal samples, there is a range of error since up to $5 \%$ cells showed monosomy of either chromosome 1 or 7. Confusing data could be a result of the two signals being superimposed (monosomy), incomplete hybridization, or non-specific binding of the probe (trisomy, etc.). Thus, data need to be interpreted with caution where small percentages of cells are being considered as being representative of a "clone."

Figure $1 \mathrm{a}$ and $\mathrm{b}$ demonstrates detection of the two chromosomes by the in situ hybridization method. It can be seen clearly that the interphase cells, which represent mature myeloid cells, all have two normal chromosomes 1 as identified by the FITC label in Figure 1a. On the other hand, there is only one chromosome 7 seen in all of these cells as shown by the blue staining of alkaline phosphatase in Figure 1b. Morphological recognition that these were mature myeloid cells was possible because of counterstaining with DAPI which outlined the nuclei of these cells distinctly (Fig. 1b). The cellular integrity was found to be more efficiently preserved in hybridizations carried out on cells deposited by cytocentrifugation of single cell suspensions than by other techniques.

Table I also summarizes the in situ hybridization data along with the clinical and cytogenetic information on these six patients. The first three patients were studied during florid AML. Almost all metaphase cells examined by G-banding showed monosomy 7 (Table I). By in situ hybridization, we detected monosomy 7 in the majority of blasts $(82,75$, and $77 \%)$, but 8,15 , and $12 \%$ cells respectively did not show monosomy 7 . These patients were noted to have $14 \%, 22 \%$, and $44 \%$ mature granulocytes or lymphocytes and monocytes on differential counts. Thus, it is not surprising that interphase analysis showed the presence of many normal cells that did not contain the -7 phenotype. The two patients studied at remission or following bone marrow transplant had normal cytogenetics and $76 \%$ and $80 \%$ normal interphase chromosomes 1 and 7 respectively. A small number of cells $(9 \%)$ were identified in the PB of patient JG with a monosomy 7 by in situ hybridization. Since there were no circulating blasts in the blood of this patient, only mature cells from PB were available for study. In control experiments using normal lymphocytes and BM cells we have found approximately $4 \%$ nuclei showing one spot with probe $\mathrm{p} \alpha \mathrm{tl}$ 
TABLE II. Frequency of Chromosomes 1 and 7 Signals Detected in Interphase Cells of "Normal" Controls and Patient Samples Corresponding to Table I

\begin{tabular}{|c|c|c|c|c|c|c|c|c|c|c|c|c|c|c|}
\hline \multirow{3}{*}{$\begin{array}{l}\text { No. chromosome } 7 \text { signals: } \\
\text { No. chromosome } 1 \text { signals: }\end{array}$} & \multicolumn{13}{|c|}{ Interphase cells with frequency of chromosomes 1 and 7 signals per cell } & \multirow{3}{*}{$\begin{array}{c}\text { Total cells } \\
\text { analyzed }\end{array}$} \\
\hline & 1 & 1 & 1 & 1 & 2 & 2 & 2 & 3 & 3 & 3 & 3 & 4 & 4 & \\
\hline & 1 & 2 & 3 & 4 & 1 & 2 & 3 & 1 & 2 & 3 & 4 & 1 & 2 & \\
\hline \multicolumn{15}{|l|}{ Controls } \\
\hline 1. Normal PB & 5 & 11 & 0 & 0 & 10 & 166 & 6 & 1 & 5 & 1 & 0 & 0 & 2 & 207 \\
\hline 2. Normal BM & 5 & 0 & 0 & 0 & 11 & 176 & 6 & 0 & 1 & 5 & 1 & 0 & 2 & 207 \\
\hline \multicolumn{15}{|l|}{ Patients } \\
\hline 1. SW & 9 & 172 & 7 & 0 & 4 & 16 & 2 & 1 & 0 & 0 & 0 & 0 & 0 & 211 \\
\hline 2. RS & 6 & 162 & 3 & 0 & 3 & 33 & 2 & 2 & 2 & 3 & 0 & 0 & 0 & 216 \\
\hline 3. $\mathrm{JC}$ & 8 & 160 & 7 & 0 & 3 & 25 & 2 & 0 & 1 & 1 & 0 & 0 & 0 & 207 \\
\hline 4. $\mathrm{JG}$ & 5 & 18 & 0 & 0 & 10 & 153 & 6 & 1 & 5 & 2 & 0 & 0 & 0 & 200 \\
\hline 5. PS & 6 & 8 & 1 & 0 & 9 & 167 & 7 & 0 & 6 & 2 & 0 & 0 & 2 & 208 \\
\hline \multirow[t]{2}{*}{ 6. TA } & 7 & 117 & 1 & 0 & 7 & 58 & 4 & 2 & 4 & 2 & 0 & 0 & 0 & 202 \\
\hline & 11 & 124 & 0 & 0 & 8 & 49 & 0 & 2 & 2 & 1 & 0 & 0 & 1 & 198 \\
\hline
\end{tabular}

in a total of 1,000 nuclei analyzed by using the double hybridization protocol. Therefore whether $9 \%$ of cells in JG with the -7 abnormality indicates the persistence of the leukemic clone that can differentiate or is due to incomplete hybridization of the probe cannot be determined at the present time.

Patient TA, who has had an indolent myelodysplastic syndrome for the last $5 \mathrm{yr}$, has been studied twice for in situ hybridization. While he has only normal mature cells in the blood, $58 \%$ and $63 \%$ of these demonstrate the presence of monosomy 7 (Table I). Clearly, the mature cells in this case were derived from the abnormal clone. The fact that these -7 cells have retained their ability to differentiate in vivo could explain the relatively benign course of his disease.

\section{DISCUSSION}

AML is a monoclonal disease in which a hematopoietic precursor cell has undergone malignant transformation $[12,13]$. Remission is usually achieved by intensive chemotherapy which reduces the leukemic burden to a level which is low enough to allow normal hematopoiesis to resume. It has become apparent over the last two decades, however, that mechanisms other than production of aplasia and repopulation by normal cells may be operative in the achievement of a complete remission (CR). For example, several cases of acute promyelocytic leukemia have been described recently where remission was achieved without intermediate marrow hypoplasia following intensive combination chemotherapy [14]. This suggests that the induction of differentiation may be a likely mechanism of response. While the possibility of inducing leukemic cells to differentiate has been a subject of ongoing discussion, evidence that mature cells during remission may actually be derived from a leukemic clone has only recently appeared.
Two different types of studies have provided proof of differentiation in leukemic cells. Firstly, by studying patients who were heterozygous for the X-chromosomelinked enzyme glucose-6-phosphate dehydrogenase (G6PD), Fialkow et al. have documented clonal development, stem cell differentiation, and monoclonality in and during complete remissions in AML patients $[15,16]$. Secondly, Fearon et al. have used recombinant DNA probes to detect clonal populations of granulocytes in AML patients and have provided evidence that in some patients, leukemic blast cells differentiate to form mature cells [17]. However, while G6PD studies can be performed on a rare individual for obvious reasons, using DNA probes on Southern blots such as those used by Fearon et al. only provides information on a population of cells as a whole.

The in situ hybridization techniques we have used to identify chromosomes in interphase cells are superior to other techniques because they provide information on individual cells and can also be performed when only a few cells are available. Data provided in the present report demonstrate the feasibility of studying interphase cells in patients with active leukemia during complete remission and myelodysplastic disorders. We identified five patients with AML and one with MDS all of whom had demonstrated monosomy 7 by conventional Gbanding techniques. Two probes against repetitive DNA sequences on chromosomes 1 and 7 provided the following pertinent data in interphase cells of these patients.

First, in patients with active leukemia $75-80 \%$ of interphase blast cells contained only one chromosome 7 and two chromosomes 1 as expected. This interphase identification of chromosomes seems more sensitive than conventional metaphase preparations because in these three patients (SW, RS, and JC in Table I), only one normal metaphase was identified in patient JC, yet in situ hybridization of interphase cells demonstrated normal 

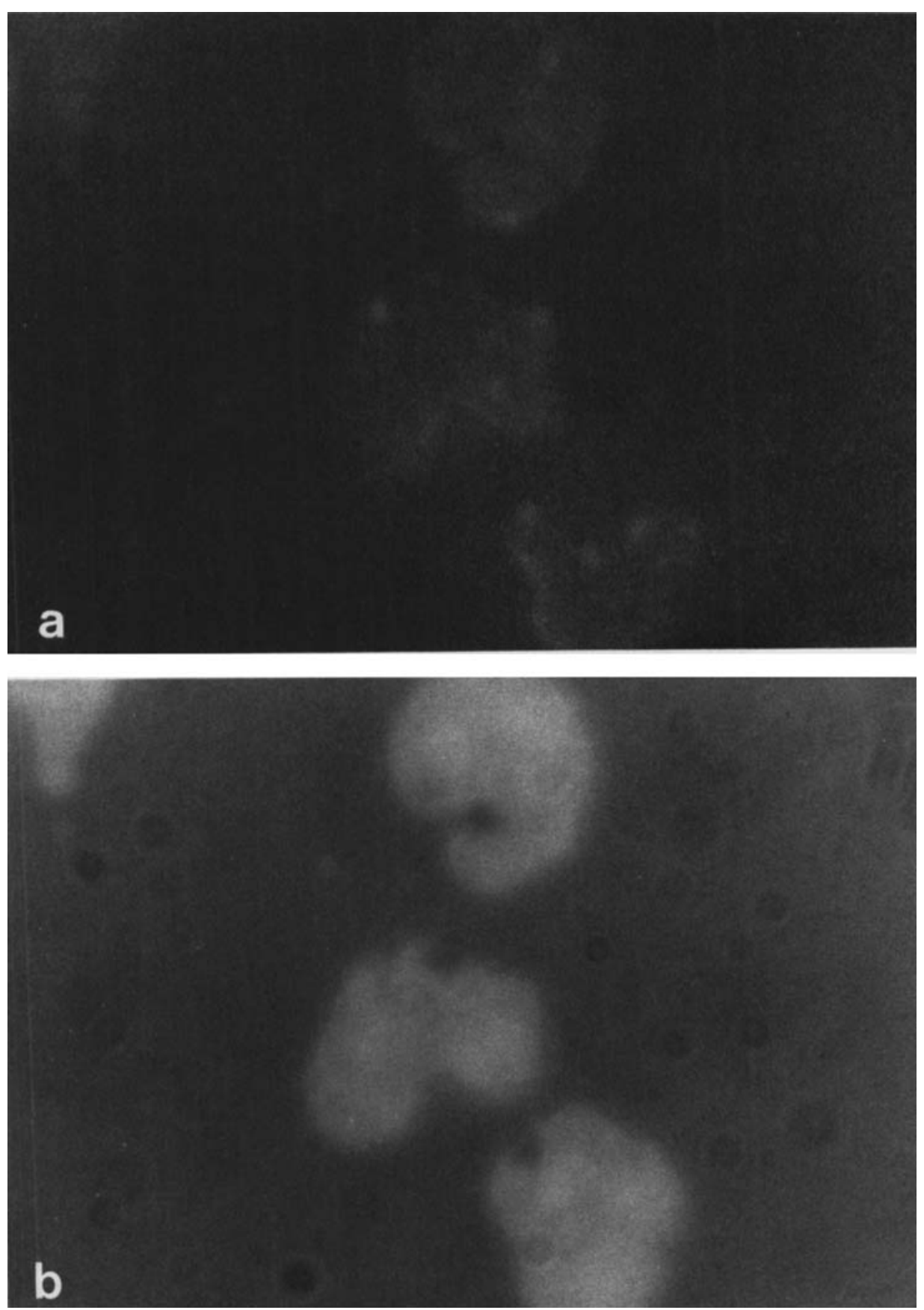

Fig. 1. Interphase nuclei from a patient with monosomy 7 after double hybridization with (a) chromosome 1 (AAF/FITC); and (b) chromosome 7 (Biotin/alkaline phosphatase) counterstained with DAPI.

cells in all three patients in addition to those containing monosomy 7. Second, in the patients JG and PS, only normal metaphases were observed by cytogenetic analysis, however, at the time of in situ hybridization, $9 \%$ and $4 \%$ cells showed monosomy 7 respectively. JG relapsed within 3 months of this finding. The significance of finding a few cells with monosomy 7 in patient PS are still unclear. It must be remembered, however, that a small percentage of monosomy 7 cells may be within the range of error; for example, a small percentage of interphase nuclei may have both chromosome 7 signals lying in the same plane. In addition, incomplete hybridization or non-specific binding of probes may give rise to false signals. As seen in Table II, up to 5\% "normal" periph- 
eral blood or bone marrow cells showed monosomy for either chromosome 7 or chromosome 1 . Therefore caution is indicated in order to avoid overinterpretation of data. Patient PS has received an allogeneic bone marrow transplant from her HLA-matched brother, and her cytogenetics now reveal a normal 46XY karyotype. It will be interesting to use a probe specific for the $\mathrm{X}$ chromosome and chromosome 7 simultaneously in this patient to see whether the monosomy 7 which is seen in very few cells at this time is present in donor cells or whether some of the patient's own cells survived due to an ineffectual preparative regimen. These studies are currently underway in our laboratory.

Finally, TA, who has had a myelodysplastic syndrome (Table I) for $5 \mathrm{yr}$, clearly has cells that have monosomy 7 , yet are fully differentiated. Obviously, monosomy 7 may not be the only abnormality in this patient since we have little information regarding the numberical status of other chromosomes in interphase cells. Interestingly enough, the presence of monosomy 7 in a cell does not necessarily mean a loss of ability to differentiate. Perhaps, the fact that the differentiation pathway is intact in these cells is one explanation for the rather benign nature of his illness. We have already reported that in vivo differentiation as documented by the appearance of bromodeoxyuridine (BrdU) in granulocytes obtained by serial sampling in AML patients is a good prognostic sign [18]. Once again, the fact that the maturation pathway is intact in these individuals seems to be associated with a less aggressive type of leukemia [18]. We have now combined interphase cytogenetics with the use of a monoclonal anti-BrdU antibody in a triple label technique which will permit more detailed cell cycle studies in in situ hybridized cells.

Therefore, in summary, while conventional cytogenetics provide information on mitotic cells, which usually constitute a very small proportion of the cells in a population, interphase cytogenetics can examine every cell including terminally differentiated cells such as granulocytes. With similar information collected on large numbers of AML patients, the definition of "complete remission" may have to be revised in this disease.

\section{ACKNOWLEDGMENTS}

The authors wish to thank Dr. Huntington Willard for making $P \alpha 7 \mathrm{tl}$ available to us. Puc 1.77 was obtained from the laboratory of Dr. Laura Manuelidis. This work was carried out in the laboratories of Dr. A.J. Kinniburgh, Dept. of Human Genetics, and Dr. Azra Raza, Dept. of Hematologic Oncology, Roswell Park Memorial Institute. Support for this work was provided in part by Grant CA-43661 (A.K.) and in part by CA-41285 (A.R.).

\section{REFERENCES}

1. Sachs L: The differentiation of myloid leukemia cells. New possibilities for therapy. Br J Haematol 40:509, 1978.

2. Koeffler HP: Induction of differentiation of human acute myelogenous leukemia cells: Therapeutic implications. Blood 62:709, 1983.

3. Cremer T, Landegent S, Bruckner A, School H, Schardin M, Hager H, Devilee P, Pearson PL, Van der Ploeg, M: Detection of chromosome aberrations in the human interphase nucleus by visualization of specific target DNAs. Hum Genet 74:346, 1986.

4. Pinkel D, Gray S, Trask B, Van den Engl G, Fuscor JJ, Van Dekker JH: Cytogenetic analysis by in situ hybridization with fluorescently labeled nucleic acid probes. "Cold Spring Harbor Symp Int Biol," 1986, Vol L1, p 151

5. Rappold G, Cremer T, Hager H, Danes K, Muller C, Yang R: Sex chromosome positions in human interphase nuclei as studied by in situ hybridization with chromosome specific probes. Hum Genet 67:312, 1984.

6. Cremer T, Tesing D, Hopman AHN, Manuelidis EL: Rapid interphase and metaphase assessment of specific chromosomal changes in neuroectodermal tumor cells by in situ hybridization with chemically modified DNA probes. Exp Cell Res (in press).

7. Hopman AHN, Wiegant J, Raap AH, Landegent JE, Van der Ploeg M. Van Duijn P: Bicolor detection of two target DNAs by non-radioactive in situ hybridization. Histochemistry 85:1, 1986.

8. Cooke HJ, Hindley JT: Cloning of human satellite III DNA: Different components are on different chromosomes. Nucleic Acids Res 6: $3177,1979$.

9. Waye JS, England SB, Willard HF: Genomic organization of alpha satellite DNA on human chromosome 7: Evidence for two distinct alphoid domains on a single chromosome. Mol Cell Biol 7:349, 1987.

10. Manuelidis L, Ward DC: Chromosomal and nuclear distribution of the Hind III 1.9 Kb human DNA repeat segment. Chromosoma 91:28, 1984.

11. Landegent $\mathbf{J}$, Jansen I, de Wal $\mathbf{N}$, Baan $\mathbf{R}$, Hoeijmakers $\mathbf{J}$, Van der Ploeg M: 2-Acetylaminofluorene modified probes for the indirect hybrido cytochemical detection of specific nucleic acid sequences. Exp Cell Res 153:61, 1984.

12. Jacobson JR, Sacher RA, Fialkow PJ: Clonal presentation of acute leukemia in relapse. Blood 52:255, 1978

13. Fialkow PJ, Singer JW, Adamson JW, Vaidya K, Dow LW, Ochs J, Moohr JW: Acute nonlymphocytic leukemia: Heterogeneity of stem cell origin. Blood 57:1068, 1981

14. Kantarjian HM, Keating MJ, McCredie KB, Beran M, Walters R, Dalton WT Jr, Hittelman W, Freireich EJ: A characteristic pattern of leukemic cell differentiation without cytoreduction during remission induction in acute promyelocytic leukemia. J Clin Oncol 3:793, 1985.

15. Fialkow PJ, Singer JW, Raskind WH, Adamson JW, Jacobson RJ, Bernstein ID, Don LW, Najfeld V, Veith R: Clonal development, stem cell differentiation and clinical remissions in acute nonlymphocytic leukemia. N Engl J Med 317:478, 1987.

16. Jacobson RJ, Temple MJ, Singer JW, Raskind W, Powell J, Fialkow PJ: A clonal complete remission in a patient with acute nonlymphocytic leukemia originating in a multipotent stem cell. N Engl J Med 310:1513, 1984.

17. Fearon ER, Burke PJ, Schiffer CA, Zehnbauer BA, Vogelstein B Differentiation of leukemia cells to polymorphonuclear leukocytes in patients with acute nonlymphocytic leukemia. N Engl J Med 315:15, 1986

18. Raza A, Mandava N, Gezer S, Hassan A, Soni N, Grande C, Presiler HD: Detection of in vivo differentiation in myeloid leukemias. In Waxman S, Rossi GB, TAkaku F (eds): "The Status of Differentiation Therapy of Cancer," Vol. 45. Serona Symposia, Raven Press, 1988, p 287. 